\title{
Foreign Direct Investment and Human Development in Cameroon
}

\author{
Olga Marthe Mbang \\ University of Yaoundé II-Soa, Yaoundé, Cameroon \\ Email: olgambang@yahoo.fr
}

How to cite this paper: Mbang, O. M. (2022). Foreign Direct Investment and $\mathrm{Hu}-$ man Development in Cameroon. American Journal of Industrial and Business Management, 12, 58-72.

https://doi.org/10.4236/ajibm.2022.121005

Received: November 14, 2021

Accepted: January 25, 2022

Published: January 28, 2022

Copyright (อ 2022 by author(s) and Scientific Research Publishing Inc. This work is licensed under the Creative Commons Attribution International License (CC BY 4.0).

http://creativecommons.org/licenses/by/4.0/ (c) (i) Open Access

\begin{abstract}
The objective of this paper is to analyze the effect of net foreign direct investment revenues on human development in Cameroon through its Human Development Index (HDI). The data used are from secondary sources, ranging from 1995 to 2019, and are mainly from the 2018 World Development Indicator (WDI) and the United Nations Development Program (UNDP). For this reason, we have carried out, through the estimation of an auto-regressive distributed lagged model (ARDL), tests of the stationary (Dickey-Fuller Augmented) and of the co-integration of (Johansen), on the variables defined before appreciating the Vector Error Correction Model (VECM). The results are at two levels. In the long term, there is a positive relationship between the two variables, which is simply justified by the fact that trade opening strengthens access to larger markets and thus contributes to the HDI. This situation offers wider consumer ranges and it could likely, therefore, help to attract more multilateral companies; in the short term, however, the relationship between the two variables is negative. This may be primarily due to the fact that export revenues are not used in the context of human capital enhancement, or that the HDI is influenced by spending on education. The government's priority should be to maintain and diversify its investments in social infrastructure and to encourage investments in labor-intensive sectors that benefit the poorest, such as agriculture, social, and infrastructure.
\end{abstract}

\section{Keywords}

Foreign Direct Investment, Human Development

\section{Introduction}

Foreign Direct Investment (FDI) remains one of the channels through which globalization can help developing countries. FDI is central to the development 
strategies of all countries, especially developing countries. These flows are favoured over other forms of capital flows because they can be an important means of acquiring stable technical skills and constitute a long term commitment to the host country. FDI is also sought for its ability to promote economic growth, notably through the development of domestic investment, job creation, or as a means of accelerating human development, reducing poverty, etc. Indeed, it has always proved to be a very effective tool for promoting economic growth. Equally, they have always proved to be more reliable than other forms of foreign capital even in the midst of financial crises. The United Nations Millennium Development Goals ${ }^{1}$, aims to accelerate human development and reduce poverty in developing countries. It is clear that most African countries are not on track to achieve these goals. As a result, considerable capital investment is needed to turn things around. In most developing countries like ours, the private sector is the main engine of growth and FDI appears to be an important source of capital investment and therefore a key factor in achieving the MDGs. However, in view of the persistent financial and economic crises in the world, developed countries are designing economic and fiscal policies that focus on keeping capital at home. The behavior of these countries further undermines the achievement of the MDGs ${ }^{2}$. On the other hand, the level of development of our countries requires continued foreign investment to stimulate the economy, reduce poverty and improve welfare. We can deduce that there is a relationship between increased FDI and improved welfare. Like other countries, the role of foreign direct investment in Cameroon has become essential to their development because of the positive externalities it generates in the economy.

This paper examines the links between net Foreign Direct Investment (FDI) inflows and welfare improvement in Cameroon. It attempts to determine whether FDI actually contributes to welfare improvement in Cameroon and to assess its impact on the selected variables before formulating policy recommendations based on our results. The HDI is chosen as the main indicator for measuring levels of human development index that is an improvement in well-being. In order to ensure robustness and control of the data, we also use real GDP per capita, which is another measure of well-being generally used in this type of analysis. In addition, the measurement of FDI was done through the net FDI inflows per capita as well as the ratio of net FDI inflows to GDP. This study is crucial for our country given the frequent economic difficulties it is facing and the current health crisis (COVID19 pandemic).

\section{Review of the Literature}

\subsection{Theoretical Lessons on the Impact of FDI on HD}

Neoclassical theories remain the first to consider FDI as a catalyst for economic growth. They show that the contribution of capital can favour the increase of the

${ }^{1}$ The achievements of this objectives were aimed for 2015. Consult http://www.un.org/fr/millenniumgoals/.

${ }^{2}$ Since the attainment of these objectives was foreseen 5 years ago. 
production of the host countries, in particular of the developing countries where the unemployment rate is high and the local savings insufficient. Thus, Solow's (1956) model, with the hypothesis of decreasing returns to scale of capital, assumes that countries with a low initial level of capital stock per capita tend to have high growth rates. This will facilitate, in the long run, their convergence with the advanced countries. In Robert M. Solow's model, the impact of FDI on growth is constrained by the rule of diminishing returns. The latter means that FDI affects per capita production only in level and in the short term.

On the other hand, long-term growth can only take place through the introduction of technological improvements which, according to him, constitute an exogenous factor. This hypothesis has been developed in the endogenous growth models; Balasubramanyam et al. (1996), Bende-Nabende \& Ford (1998) or Borensztein et al. (1998), De Mello (1999), who consider knowledge, a source of productivity gains, as a particular type of capital. The basic idea is that capital accumulation contributes to the collective creation of new technological and organizational knowledge. This knowledge creation offsets the effect of diminishing returns to capital and allows the economy to maintain a sustained growth rate in the long run, subject to appropriate assumptions about the externalities of learning.

Indeed, since the Second World War, the evolution of FDI in developing countries shows two trends. Between the end of the Second World War and the end of the Cold War in the early 1990s, at that time, FDI flows and volumes increased in the world in general and in developing countries in particular. During this period, FDI flows were mainly driven by political rather than economic motives. Now, since the 1990s, FDI has focused on countries that offer financial benefits, subsidies and other incentives. The impact of FDI on human development can be analyzed from at least three perspectives. In developing countries, government priorities are focused on education, life experience, GDP per head, poverty reduction and welfare improvement. Foreign investment can contribute to these goals by creating jobs, developing local skills and stimulating technological progress.

Although there seems to be a consensus at the theoretical level regarding the positive impact of FDI on economic growth, human capital, income, employment, technology transfer, poverty reduction and inequality, the results of empirical studies that have attempted to verify these positive impacts are not generally conclusive. FDI promotes economic growth and this is a necessary condition for poverty reduction (Jalilian \& Kirkpatrick, 2002; Dollar \& Kraay, 2002).

Nelson \& Pack (1999) and Kakwani (2000) confirm the findings and add that an increase in the growth rate of GDP per capita is strongly correlated with the average income of the poor. FDI in the host country can have both direct and indirect effects on poverty reduction. The indirect impact of FDI on poverty reduction is manifested through economic growth, which is reflected in improved living standards due to increased GDP, improved technology and productivity, and an improved business environment. 


\subsection{Empirical Lessons on the Impact of FDI on HD}

The literature dealing specifically with the impact of FDI on HD is particularly scarce. Nevertheless, one can find some that deals with the interaction that develops or not with variables such as human capital, knowledge transfer, productivity, employment, technology transfer, poverty reduction, income, inequality, etc. Currently, economists tend to recognize a positive global effect of FDI on the growth of developing countries but with often important nuances (Mainguy, 2004).

\section{- FDI and knowledge transfer}

In fact, as some studies show, FDI has little chance of transferring technology and having a positive impact on growth if there is not a minimum stock of human capital in the host country. Thus, Borensztein, De Gregorio, \& Lee (1994), among others, have carried out an in-depth estimation of the relationship between FDI and growth for a sample of sixty-three countries between 1970 and 1989. To the extent that FDI and domestic investment appear complementary, FDI is positively related to per capita product growth so that for each additional percentage point of the FDI/GDP ratio, the growth rate is 0.8 points higher. Taking into account across term between FDI and schooling ${ }^{3}$, allows FDI to have a positive effect on growth.

The autonomous effect of FDI thus disappears. All in all, it seems that, in spite of controversies, empirical works conclude to a positive effect of the availability of qualified labour as a strong condition of the effectiveness of FDI. This is all the more important as factor productivity also depends on it. Blomström \& Kokko (1996) show that technology transfer between multinationals and their subsidiaries does not only take place through machinery, equipment, patent rights and expatriation of managers and technicians, but also through the training of local employees of the subsidiaries.

\section{- FDI and Human Capital}

Borensztein et al. (1998) based on the work of Barro \& Lee (1994) show that the stock of human capital is essential to determine the amplitude of the effects of the FDI on the growth, by adding that in the countries where the level of human capital is weak, the effects can be negative. During the same year, a study of Borensztein et al. (1998), conditions the attractiveness of the FDI by reaching a certain threshold of human capital development. They show that, from the threshold of 0.52 years of secondary education, the host country benefits from productivity gains via FDI. Xu (2000), goes in the same direction as his predecessors but this time, shows that it is rather starting from a threshold limit of 1.9 year of secondary studies that the FDI starts to involve gains of economic growth in the host country. From the results of both papers, it is clear that most developing countries have already reached the Borensztein et al. development threshold, but not the Xu threshold.

Temple (2001) in a study conducted within the Organization for Economic Cooperation and Development (OECD) countries, shows that investment in ed-

${ }^{3}$ Schooling is measured here by the average number of years of study in secondary school. 
ucation and other forms of human capital are essential for a country to offer a favourable climate for FDI. Indeed, the human capital stock is both a factor that determines the quantity and quality of inward FDI flows, and a mechanism that can be developed through FDI. (Ritchie, 2002) and (Lipsey \& Sjöholm, 2004) have shown that multinationals invest more in training than local firms. They acknowledge that multinationals have played an important role in the growth of Southeast Asia, and Indonesia for the second author, as long as they influence the educational institutions of the host countries, by investing more in the training of local firms. In more recent studies, they stress the relative importance of MNCs in higher education. In more recent studies, they emphasize the relative importance of MNCs in higher education. They state that "Although the role of MNCs is quite marginal in primary and secondary education, FDI could nevertheless have a visible effect on higher education in host countries". Research on the relationship between FDI and human capital formation needs to be further investigated and raises the question of what public policies should be implemented to improve the absorptive capacity of host countries.

\section{- FDI and Productivity}

Azeroual (2016), studies the impact of foreign direct investment (FDI) on Total Factor Productivity (TFP) in Morocco during the period 1980-2012. Using the Vector Error Correction Model (VECM), he demonstrates that FDI does not explain total factor productivity in the same way. In this respect, only FDI from France is statistically significant and has a positive effect on TFP. This is due, according to him, to the concentration of these investments in the industrial sector which is one of the catalyst sectors for the transfer of know-how, technology and economic growth.

\section{- FDI and poverty reduction}

Some empirical studies suggest that FDI is very important as long as it is a source of capital. It complements private investment and creates new employment opportunities, as well as technology transfer and stimulates economic growth in host countries. (Jalilian \& Kirkpatrick, 2002), as well as (Dollar \& Kraay, 2002) show that the impact of FDI can be direct or indirect in host countries. The first impact is due to economic growth which translates into improved living standards, due to the increase in GDP, improved technology and productivity, as well as economic development. The direct impact can be seen through the increase in employment and the reduction in the population living below the poverty line, resulting from the demand for employment and the improvement of the labour force. FDI promotes economic growth and this is a necessary condition for poverty reduction.

In the same year, Agenor (2002) finds no significant correlation between FDI and poverty. He starts from a sample of 11 middle and low income countries during the period 1988-1998, using OLS with fixed effects. Milanovic (2003), on the other hand, in a study using household survey data for over 80 countries over the period 1988, 1993 and 1998. He estimates from OLS and GMM, respectively, the fixed effects and lagged values of endogenous variables as instruments. He ar- 
rives at the results that there is no association between FDI and income distribution, regardless of the income level. (Mirza \& Giroud, 2004) examined the effects of the FDI on poverty for a sample of 26 countries. They consider 13 developing countries, 10 developed countries and 3 new emerging economies. They find that regardless of the country category, the direct effect of FDI on poverty is through employment and labour force training. Unlike the previous authors, Muhamad's (2007) study focuses on the impact of FDI on poverty in Pakistan only. He notes that there is a positive result that shows the important role of FDI in reducing urban poverty in Pakistan. The negative result between FDI and rural poverty is increasing day by day without a significant impact on rural households.

Nguyen (2007) showed the contribution of FDI to poverty reduction in Vietnam in the years 1990-2000. During this period with increased FDI, the country experienced high economic growth, considerable poverty reduction and better terms of trade. FDI is considered an integral part of the economy. The study points out that the direct impact of FDI works through job creation. The indirect impact of FDI works through economic growth and through the contribution of FDI to local budgets. Regarding the contribution of FDI to growth, the estimated coefficients are significantly positive and based on panel data covering 61 provinces in Vietnam during this period. Moreover, the results show that FDI interacts positively with local human capital, affecting economic growth. It concludes that poverty reduction in Vietnam is directly affected by economic growth and FDI. And, FDI has positive effects on growth, which in turn contributes to poverty reduction in Vietnam. Noomen (2009), on the other hand, focuses on SubSaharan Africa, to analyze the effects of FDI on poverty reduction between 1990 and 2005 through two mechanisms: institutional and economic.

The first mechanism is based on a principal component analysis and shows that manufacturing FDI is positively correlated with development, the investment climate and poverty reduction. The second mechanism is divided into two parts. On the one hand, multinational firms can either crowd out or stimulate local firms. The application of the GMM estimation method of (Arenallo \& Bond, 1991) on a panel of countries in the sub-region shows that FDI has crowding out effects on local investments. On the other hand, FDI affects absolute poverty through its effects on growth and inequality. Using simultaneous equation estimation techniques on panel data, the study finds that FDI in extractive industries is growth-enhancing but increases inequality. Therefore, the increase in FDI in extractive industries would be followed by an increase in the absolute poverty rate.

(Okpe \& Abu, 2009) examined the effects of foreign private investment on poverty reduction in Nigeria alone. Using regression analysis for the period 1975-2003, the test shows that the inflow of FDI and foreign loans in Nigeria significantly alleviates poverty. The study also shows that government expenditure and continuous increase in tax on oil profits worsen the level of poverty in Nigeria. The study therefore suggests that the inflow of foreign resources such as 
FDI should be encouraged while strongly discouraging foreign lending. The removal of oil profit tax allows existing businesses not to be the closed shops and stimulate the entry of new businesses.

In order to examine the relationship between the above two variables, Ucal (2014) examined the relationship FDI and poverty reduction at the macro level in developing countries. The study shows that the contribution of FDI from host countries can take several forms, such as technology transfer, human capital development, increased competition in domestic markets, and corporate tax generation. Results from the examination of a dataset and an econometric model to analyze FDI flows and poverty reduction show that, there is a statistically significant relationship between FDI and poverty and there is evidence that FDI reduces poverty in developing countries.

At the end, the conclusions of the existing analyses are mixed, but most of the studies have attempted to empirically validate the supposed link between the two FDI variables and poverty reduction through their methodologies, samples and results. Indeed, these economic studies rely on theoretical evidence of the existence of a direct or indirect causal relationship between FDI and poverty reduction.

\section{- IDE poverty and income}

(Calvo \& Hernandez, 2006) conduct a study on 20 Latin American countries to show the impact of the FDI stock on poverty. They succeed in showing that the impact varies according to the country. Thus, only countries with low FDI potential, classified by UNCTAD, show a significant relationship between FDI stock and poverty reduction. The stock of FDI in other regions does not seem to have a significant impact on the incidence of poverty. Studies on the relationship of FDI on wage inequality have provided fairly consistent evidence. They show that FDI increases income inequality, at least in the short run, for all 20 countries. These findings are consistent with Tsai (1994) on developing countries who find that FDI exacerbates intra-country income inequality. (Nunnenkamp, Schweickert, \& Manfred, 2006) conduct a single-country study in Latin America, specifically Bolivia, to analyze the impact of foreign direct investment (FDI) on poverty and income distribution. It proposes a CGE analysis of the medium- and long-term impact of FDI inflows on poverty and income distribution in Bolivia.

The simulation results suggest that FDI inflows improve economic growth and reduce poverty. However, income distribution generally becomes more unequal. FDI increases the disparities between urban and rural areas. Therefore, labour market segmentation needs to be overcome by providing complementary public investment in infrastructure. Koc (2012) studied the relationship between foreign direct investment and poverty for a sample of 40 developed and developing countries. From an analysis in they show that the poorest individuals receive a smaller share of income created by FDI than the richest individuals in these countries. The study concludes that FDI does not make a serious contribution to poverty reduction. FDI affects the income levels of different groups in each country unevenly. 


\section{- FDI, growth, poverty reduction and income}

Studies by United Nations Conference on Trade and Development (2005), examined the relationship between FDI and poverty for a sample of 40 countries during the years 1980-2008. Using econometric models on panel data, the results show that FDI increases the incomes of the middle and poor groups, and negatively affects the incomes of the richest groups ${ }^{4}$. While FDI increases the incomes of rich and poor groups, it reduces the incomes of the middle groups ${ }^{5}$. FDI has negative income effects in Russia and Georgia. Shahbaz \& Aamir (2008), bring in additional variables in their analysis and show that the direct and indirect effect of FDI on poverty reduction can vary depending on quantitative or qualitative factors (labor, capital intensive), type of investment (Greenfield, M\&A investment, privatization), conditions of the investment sector, technological improvements, taxes paid by FDI and how they are spent, efficiency of investments and wages.

These factors are affected by economic and political conditions which are one of the most important determinants of the impact of FDI on poverty. The indirect impact of FDI on poverty reduction is manifested through economic growth which is reflected in improved living standards due to increased GDP, improved technology and productivity and improved business environment. In the same line of work, Gohou \& Soumaré (2012) also examine the relationship between FDI, growth and poverty reduction.

Using econometric models on panel data in African countries, they find a contribution of FDI to poverty reduction in Africa. Using data on variables such as GDP and FDI, they chose to use ratios such as net FDI flows plus gross capital formation, in order to obtain more accurate and detailed results. They also use the human development index rather than using GDP as a variable in order to obtain more specific results on welfare. The study manages to show that there is a causal link between FDI and GDP per capita. Therefore, FDI reduces poverty and increases welfare.

On the other hand, it indicates that the relationship between FDI and welfare varies considerably between regions of Africa and between Africa and other regions of the world. For example, FDI affects welfare in Central and East Africa, although its impact in the North and South remains insignificant. Kouame (2019) in his paper assesses the impact of foreign direct investment (FDI) on poverty reduction, both directly and through its effects on growth and inequality, in the WAEMU. Thus, using panel data over the period 1990-2017 and a model with three simultaneous equations, the results show that FDI directly reduces poverty, measured by the Human Development Index (HDI), but not through its effects on growth and income inequality. Therefore, it is in the interest of the authorities to provide incentives in labour-intensive sectors to redirect FDI towards activities in which poor people are most active.

${ }^{4}$ The countries that made up this group are: Bangladesh, Belarus, Bulgaria, China, Ivory Coast, Croatia, Estonia, Hungary, Kazakhstan, Kyrgyzstan, Latvia, Pakistan, Poland, Romania and Ukraine.

${ }^{5}$ The countries in this group are; Uganda and the Philippines. 
An attempt has been made to review the empirical literature on FDI and the main variables such as: knowledge transfer, human capital, productivity, poverty reduction, income, economic growth and poverty reduction. It is found that most empirical studies on the relationship between FDI and the said variables show that the effects are not always positive and significant. Other studies show the often disastrous effect of FDI.

\section{Methodology}

The empirical verification of the effect of FDI on HD in the case of Cameroon, is done through the estimation of an autoregressive model $\left(\mathrm{VAR}^{6}, \mathrm{VECM}^{7}\right.$ or $\left.\mathrm{ARDL}^{8}\right)$ as in (Azeroual, 2016). The specification of one of the following models depends on the conditions of stationarity and cointegration of variables.

\subsection{Presentation of Variables and Data}

The data used in this study are all from secondary sources, ranging from the period 1995 to 2019. They are mostly from the World Development Indicator, and the United Nations Development Programme (UNDP). We capture HD by the variable "idh", and FDI by the variable "ide". In order to make our results more meaningful, we will add control variables such as the GDP growth rate noted "gdp", exports and imports noted respectively "exp" and "imp", and investment captured by gross fixed capital formation and noted "inv". All the control variables introduced are in percentage of GDP.

\section{- The model to be estimated}

The determination of the model to be estimated depends on the conditions of stationarity and cointegration of the variables. However, we propose a general model of the form:

$$
i d h_{t}=f\left(\text { ide }_{t}, \exp _{t}, \text { imp }_{t}, \text { pib }_{t}, i n v_{t}\right)+\varepsilon_{t}
$$

\subsection{Applications of Estimation Techniques}

As Box \& Jenkins (1976) have shown, it is not possible to carry out a study on a time series without verifying its stationary nature. Hence the need to verify the conditions of stationarity and cointegration of the variables on the one hand, before presenting the model chosen and the results of the estimates of this model on the other.

\section{- The stationarity and cointegration tests}

Let us present the Augmented Dickey-Fuller (ADF) test on the defined variables.

Table 1 presents the level and difference stationarity tests. The results of the stationarity test inform us that the variables of the model are stationary in first difference. According to the theory of cointegration, there could be a risk of cointe-

${ }^{6}$ If the variables are stationary in level.

${ }^{7}$ If the variables are stationary in difference and cointegrated.

${ }^{8}$ If these variables are integrated of different orders be I (0) and I (1), but not I (2). 
gration between the variables, which can be verified by means of the Johansen test.

\section{- Cointegration Test of Johansen (1988).}

The results of this test are shown in the following Table 2: Indeed, whether we use the maximum eigenvalue or the trace criterion, the results of cointegration test inform us that the variables of the model are cointegrated. There is therefore a LT or cointegrating relationship between them.

Table 1. Stationarity test of variables (Dickey \& Fuller, 1981).

\begin{tabular}{|c|c|c|c|c|c|c|c|c|}
\hline \multirow{3}{*}{$\begin{array}{c}\text { Variables } \\
\text { In level }\end{array}$} & \multicolumn{3}{|c|}{ Constant and trend } & \multirow{3}{*}{$\begin{array}{l}\text { Variables } \\
\text { in } \\
\text { difference }\end{array}$} & \multicolumn{3}{|c|}{ Constant and trend } & \multirow{2}{*}{$\begin{array}{l}\text { Order of } \\
\text { integration } \\
\text { of variables }\end{array}$} \\
\hline & \multirow[t]{2}{*}{$\begin{array}{c}\text { Calculate } \\
\text { Value }\end{array}$} & \multicolumn{2}{|c|}{$p$-value } & & \multirow[t]{2}{*}{$\begin{array}{c}\text { Calculate } \\
\text { Value }\end{array}$} & \multicolumn{2}{|c|}{$p$-value } & \\
\hline & & $1 \%$ & -4.394 & & & $1 \%$ & -4.416 & \\
\hline \multirow[t]{3}{*}{ Idh } & -2.7097 & $5 \%$ & -3.612 & $\Delta \mathrm{idh}$ & -6.3090 & $5 \%$ & -3.622 & I (1) \\
\hline & & $10 \%$ & -3.243 & & & $10 \%$ & -3.248 & \\
\hline & & $1 \%$ & -4.394 & & & $1 \%$ & -4.416 & \\
\hline \multirow[t]{3}{*}{ Ide } & -3.213 & $5 \%$ & -3.612 & $\Delta$ ide & -8.804 & $5 \%$ & -3.622 & I (1) \\
\hline & & $10 \%$ & -3.243 & & & $10 \%$ & -3.248 & \\
\hline & & $1 \%$ & -4.394 & & & $1 \%$ & -4.416 & \\
\hline \multirow[t]{3}{*}{ Exp } & -3.523 & $5 \%$ & -3.612 & $\Delta \exp$ & -5.045 & $5 \%$ & -3.622 & I (1) \\
\hline & & $10 \%$ & -3.243 & & & $10 \%$ & -3.248 & \\
\hline & & $1 \%$ & -4.394 & & & $1 \%$ & -4.416 & \\
\hline \multirow[t]{3}{*}{$\operatorname{Imp}$} & -0.814 & $5 \%$ & -3.612 & $\Delta \mathrm{imp}$ & -4.695 & $5 \%$ & -3.622 & \\
\hline & & $10 \%$ & -3.243 & & & $10 \%$ & -3.248 & \\
\hline & & $1 \%$ & -4.394 & & & $1 \%$ & -4.416 & \\
\hline \multirow[t]{2}{*}{ Inv } & -2.458 & $5 \%$ & -3.612 & $\Delta \mathrm{inv}$ & -5.985 & $5 \%$ & -3.622 & I (1) \\
\hline & & $10 \%$ & -3.243 & & & $10 \%$ & -3.248 & \\
\hline Pib & -2.358 & & -4.394 & $\Delta \mathrm{pib}$ & -6.155 & $1 \%$ & -4.416 & \\
\hline
\end{tabular}

Source: Author's calculations on Logitiel Eviews 9.

Table 2. Results of the Johansen (1988).

\begin{tabular}{cccccc}
\hline H0 & $\lambda$ trace & $\begin{array}{c}\text { Values } \\
\text { read at } 0.05\end{array}$ & $\lambda \max$ & $\begin{array}{c}\text { Values } \\
\text { read at } 0.05\end{array}$ \\
Cameroon & $\mathrm{r}=0$ & $141.1560^{*}$ & 103.84 & $60.23204^{*}$ & 40.956 \\
& $\mathrm{r}=1$ & $80.92398^{*}$ & 76.97 & 31.84067 & 34.805 \\
& $\mathrm{r}=2$ & 49.08331 & 54.07 & 22.13424 & 28.588 \\
\hline
\end{tabular}

Source: Author's calculations on Logitiel Eviews 9. 
- Presentation of the model, estimates and robustness test and interpretations.

From a theoretical point of view, when variables are integrated of the same order, and they are cointegrated, a VECM model should be estimated.

Model presentation and estimation. Thus, the model to be estimated is of the form:

$$
\operatorname{Didh}_{t}=\sum_{p=1}^{k} \alpha_{p} t c e_{t-1}+\sum_{P=1}^{k-1} \beta_{p} D i d h_{t-p}+\sum_{p=0}^{t-1} \gamma_{p} D L X_{t-p}+\varphi_{k}+\varepsilon_{t}
$$

with: $t c e=\left(i d h_{t}-\theta_{k} X_{i t}\right.$ with tce the equilibrium restoring force such that $\alpha_{p}<0$ and negative;

$X_{i t}=\left(i d e_{t}, \exp _{t}, \operatorname{imp}_{t}, \operatorname{inv}_{t}, p_{i b_{t}}\right)$ is the matrix of the variables of the model in logarithm;

$\beta_{k}$ and $\gamma_{p}$ are the short run coefficients, while $\theta_{k}$ are the long run coefficients. The terms $\varphi_{k}$ and $\varepsilon_{p}$ represent the constant term and the error term.

The results of the estimates are contained in the following Table 3, which presents the results of the short-term and long-term estimates:

Table 3. Results of short-term and long-term estimates.

\begin{tabular}{ccc}
\hline & \multicolumn{2}{c}{ Endogenic variables (idh) } \\
\cline { 2 - 3 } Explanatory variables & \multicolumn{2}{c}{ Long-term relationships } \\
\cline { 2 - 3 } & Coefficients & $p$-value \\
\hline ide $(-1)$ & $-1.003^{* * *}$ & 7.477 \\
exp $(-1)$ & $0.1067^{* *}$ & 2.623 \\
imp $(-1)$ & $-0.1471^{* * *}$ & 3.999 \\
inv (-1) & $0.28441^{* *}$ & 3.692 \\
GDP & $0.2623^{* *}$ & 2.132 \\
TCE & $-0.0084^{* *}$ & 2.546 \\
& Short-term relationships \\
Explanatory variables & coefficients & coefficients \\
Dide & $-0.005^{* * *}$ & 2.437 \\
Dexp & -0.00155 & 1.46 \\
Dimp & -0.0008 & 0.795 \\
Dinv & 0.0020 & 1.56 \\
Dpib & -0.0006 & 0.643 \\
$\varphi$ I & $0.0008^{* * *}$ & 4.616 \\
\hline
\end{tabular}

Note: ${ }^{* *},{ }^{* *}$ and ${ }^{\star}$ represent the significance of the parameters respectively at the $1 \%, 5 \%$, and $10 \%$ threshold for respective values of $1.65,1.96$ and 3.65. Source: Author's calculations on Logitiel Eviews 9.

${ }^{9}$ Analyzes the cointegrating relationship between the variables. 
In the long term, the analysis of this table shows that the results obtained respect the conditions for estimating the VECM models. Indeed, the error correction term is negative and significant at the $5 \%$ threshold $(-0.0084(2.546))$, validating the idea that there is a long term relationship or cointegration between the variables of the model. We also find that in the long run, foreign direct investment (fdi) negatively influences Human Development Index (hdi) in Cameroon at the $1 \%$ threshold $\left(-1.003^{* * *}(477)\right)$. One of the main reasons for this discrepancy lies in the difficulty of defining and calculating the hdi (which is human capital), where often the average number of years of schooling or initial schooling is used to account for returns to education. These measures are calculated using the Perpetual Inventory Method (PIM), interpolation, extrapolation or subjective estimation: Portela et al. (2004), then De la Fuente \& Domenech (2006), estimate that, on average, the PIM underestimates the observed results by about one fifth of each school year every five years.

Other significant shortcomings concern missing data, differences in the classification of different levels in the data collection. In addition, measures of formal education do not take into account work training, work experience and learning by doing: Baldacci et al. (2008) have led to divergent econometric results.

In the same way, it emerges from the analysis of this table that the long-term model has a very good explanatory power for the variables (exp) $\left(0.1067^{\star *}(2.623)\right)$, (inv.) $\left(0.28441^{\star * *}(3.692)\right)$ and economic growth (gdp) $\left(0.2623^{\star *}(2.132)\right)$ which positively influence the hdi. These results simply justify the fact that trade openness enhances access to larger markets and thus contributes to hdi. For, offers wider ranges of consumers and it could presumably, therefore, help attract more MNFs (Mansouri, 2009), anything that allows us to presume a positive relationship between the two variables.

In the short term, it is only the fdi variable $\left(-0.005^{\star * \star}(2.437)\right)$ that negatively influences the hdi at only $5 \%$. Indeed, these variables have the expected signs except for exports of goods. Thus, the explanatory equation of the fdi shows that it is influenced to short term by the expenditure on education. This negative impact can also be justified by the quality of the data or the size of the sample. It can also be explained by the fact that revenues from exports are not used for human capital improvement.

\section{Conclusion}

This paper, which analyzes the effect of net foreign direct investment inflows on human development in Cameroon through its Human Development Index (HDI), led us to review the empirical literature on Foreign Direct Investment (FDI) and the main variables such as knowledge transfer, human capital, productivity, poverty reduction, income, economic growth and poverty reduction. It is found that most empirical studies on the relationship between FDI and the said variables show that the effects are not always positive and significant. Other studies show the negative effect of FDI. Our study highlights the long run and short run re- 
sults. In the long run, the variables exp, inv and GDP influence positively the HDI. These results simply justify the fact that trade openness enhances access to larger markets and thus contributes to the Hdi. But, in the short run, the FDI variable has a negative influence on the HDI through expenditure on education, mostly because export revenues are not used to improve human capital.

\section{Conflicts of Interest}

The author declares no conflicts of interest regarding the publication of this paper.

\section{References}

Agenor, P. R. (2002). Does Globalization Hurt the Poor? School of Social Sciences, University of Manchester, $56 \mathrm{p}$.

Arenallo, M., \& Bond, S. (1991). Some Tests of Specification for Panel Data: Monte Carlo Evidence and an Application to Employment Equations. The Review of Economic Studies, 58, 277-297. https://doi.org/10.2307/2297968

Azeroual, M. (2016). Foreign Direct Investment in Morocco: Impact on Total Factor Productivity by Country of Origin (1980-2012). Africa and Development, 16, 191-213.

Balasubramanyam, V. N., Salsu, M., \& Sapsford, D. (1996). Foreign Direct Investment and Growth in EP and IS Countries. The Economic Journal, 106, 92-105. https://doi.org/10.2307/2234933

Baldacci, E., Clements, B., Gupta S., \& Cui, Q. (2008). Social Spending, Human Capital, and Growth in Developing Countries: Implications for Achieving the MDGs. World Development, 36, 1317-1341. https://doi.org/10.1016/j.worlddev.2007.08.003

Barro, R. J., \& Lee, J. W. (1994). Sources of Economic Growth. Carnegie-Rochester Conference Series on Public Policy, 40, 1-46. https://doi.org/10.1016/0167-2231(94)90002-7

Bende-Nabende, A., \& Ford, J. L. (1998). An Empirical Analysis on the Contribution of Foreign Direct Investment on Nigeria Economy. School of Economics, Wuhan University of Technology.

Blomström, M., \& Kokko, A. (1996). The Impact of Foreign Investment on Host Countries: A Review of the Empirical Evidence. Policy Research Working Paper No. 1745.

Borensztein, E., De Gregorio, J., \& Lee, J. W. (1994). How Does Foreign Direct Investment Affect Economic Growth? NBER Working Paper No. w5057.

https://doi.org/10.2139/ssrn.883401

Borensztein, E., De Gregorio, J., \& Lee, J. W. (1998). How Does Foreign Direct Investment Affect Economic Growth? Journal of International Economics, 45, 115-135. https://doi.org/10.1016/S0022-1996(97)00033-0

Box, G. E. P., \& Jenkins, G. M. (1976). Time Series Analysis: Forecasting and Control (Revised Edition), Holden Day.

Calvo, C. C., \& Hernandez, M. A. (2006). Foreign Direct Investment and Poverty in Latin America. In Fifth Annual Postgraduate Conference (p. 14). University of Nottingham.

De la Fuente, G., \& Domenech, R. (2006). Human Capital in Growth Regressions: How Much Difference Does Data Quality Make? Journal of the European Economic Association, 4. https://doi.org/10.1162/jeea.2006.4.1.1

De Mello, L. R. (1999). Foreign Direct Investment-Led Growth: Evidence from Time Series and Panel Data. Oxford Economic Papers, 51, 133-151.

https://doi.org/10.1093/oep/51.1.133 
Dickey, D. A., \& Fuller, W. A. (1981). Likelihood Ratio Statistics for Autoregressive Time Series with a Unit Root. Econometrica, 49, 1057-1072. https://doi.org/10.2307/1912517

Dollar, D., \& Kraay, A. (2002). Grow this Good for the Poor. Journal of Economic Growth, 7, 195-225.

Gohou, G., \& Soumaré, I. (2012). Does Foreign Direct Investment Reduce Poverty in Africa and are There Regional Differences? World Development, 40, 75-95. https://doi.org/10.1016/j.worlddev.2011.05.014

Jalilian, H., \& Kirkpatrick, C. (2002). Financial Development and Poverty Reduction in Developing Countries. International Journal of Finance and Economics, 7, 97-108. https://doi.org/10.1002/ijfe.179

Johansen, S. (1988). Statistical Analysis of Cointegration Vectors. Journal of Economic Dynamics and Control, 12, 231-254. https://doi.org/10.1016/0165-1889(88)90041-3

Kakwani, N. (2000). Growth and Poverty Reduction: An Empirical Analysis. Asian Development Review, 18, 74-84.

Koc, S. (2012). The Effect of Foreign Direct Investment on Poverty: Panel Regression Analysis for 40 Selected Underdeveloped and Developing Countries. University of Sousse, $378 \mathrm{p}$.

Kouame, M. V. (2019). L'impact Des Investissements Directs Etrangers Sur La Réduction De La Pauvreté Dans L'UEMOA. Journal of Economics and Finance, 10, 74-85.

Lipsey, R. \& Sjöholm, F (2004). Foreign Direct Investment, Education and Wages in Indonesian Manufacturing. Journal of Development Economics, 73, 415-422. https://doi.org/10.1016/j.jdeveco.2002.12.004

Mainguy, C. (2004). Impact des Investissements Directs Etrangers sur les Economies en Développement. Revue Région et Développement, N²0, 65-90.

Mansouri, B. (2009). Effects of Foreign Direct Investment and Trade Openness on Economic Growth in Morocco. In African Economic Conference 2009.

Milanovic, B. (2003). Is Inequality in Africa Really Different? Policy Research Working Paper No. 3169, World Bank. https://doi.org/10.1596/1813-9450-3169

Mirza, H., \& Giroud, A. (2004). Regional Integration and Benefits from Foreign Direct Investment in ASEAN. Asian Development Review, 21, 66-98.

Muhamad, S. F. (2007). Impact of Foreign Direct Investment on the Fight against Poverty in Pakistan Using CGE Model. In International Economic Conference on Trade and Industry (EISTI).

Nelson, R. R., \& Pack, H. (1999). The Asian Miracle and Modern Growth Theory. The Economic Journal, 109, 416-436. https://doi.org/10.1111/1468-0297.00455

Nguyen, T. P. H. (2007). Vietnam's Impetus and the Role of Education Policy. Welt Trends.

Noomen, L. (2009). The Contribution of Foreign Direct Investments to Poverty Reduction in Sub-Saharan Africa. University of Tunis EL Manar and Université Paris-Dauphin, $322 \mathrm{p}$.

Nunnenkamp, P., Schweickert, R., \& Manfred, W. (2006). Distributional Effects of FDI: How the Interaction of FDI and Economic Policy Affects Poor Households in Bolivia. In Proceedings of the German Development Economics Conference (pp. 5-8).

Okpe, I. J., \& Abu, G. A. (2009). Foreign Private Investment and Poverty Reduction in Nigeria (1975 to 2003). Journal of Social Sciences, 19, 79-102.

https://doi.org/10.1080/09718923.2009.11892710

Portela, M. C. A. S., Thanassoulis, E., \& Simpson, G. (2004). Negative Data in DEA: A Directional Distance Approach Applied to Bank Branches. Journal of the Operational Research Society, 55, 1111-1121. https://doi.org/10.1057/palgrave.jors.2601768 
Ritchie, B. K. (2002). Foreign Direct Investment and Intellectual Capital Formation in Southeast Asia. OECD Development Center, Technical Papers, 47 p.

Shahbaz, M., \& Aamir, N. (2008). Direct Foreign Investment and Income Distribution: A Case Study for Pakistan. International Research Journal of Finance and Economics, 21, 7-18.

Solow, R. M. (1956). A Contribution to the Theory of Economic Growth. The Quarterly Journal of Economics, 70, 65-94. https://doi.org/10.2307/1884513

Temple, J. (2001). Growth Effects of Education and Social Capital in the OECD Countries. OECD Economic Studies, No. 33, 57-101. https://doi.org/10.1787/eco studies-v2001-art11-en

Tsai, P. L. (1994). Determinants of Foreign Direct Investment and Its Impact on Economic Growth. Journal of Economic Development, 19, 12-36.

Ucal, M. (2014). Analysis of Panel Data on Foreign Direct Investment and Poverty from the Perspective of Developing Countries. Procedia-Social and Behavioral Sciences, 109, 1101-1105. https://doi.org/10.1016/j.sbspro.2013.12.594

United Nations Conference on Trade and Development (UNCTAD) (2005). World Investment Report, Transnational Corporations and the Internationalization of Research and Development: An Overview. United Nations.

$\mathrm{Xu}, \mathrm{Z}$. (2000). Financial Development, Investment and Economic Growth. Economic Survey, 38, 331-344. https://doi.org/10.1111/j.1465-7295.2000.tb00021.x 